\title{
Testicular leydig cell tumor presenting as primary infertility
}

\author{
Athina Markou' ${ }^{1}$, Justin Vale ${ }^{2}$, Bhumita Vadgama ${ }^{1}$, Marjori Walker ${ }^{2}$, Stephen Franks ${ }^{1}$ \\ ${ }^{1}$ Department of Reproductive Science and Medicine, Imperial College Faculty of Medicine, ${ }^{2}$ St Mary's Hospital, \\ London
}

\begin{abstract}
A 29-year old male and his wife presented with an 18 month history of primary infertility. History and initial investigations suggested no major female pathologic component but a semen analysis revealed azoospermia. There was no history of any sexual dysfunction and neither partner was receiving any medication. Clinical examination revealed normal secondary sexual characteristics. Both testicles were of normal consistency with a volume of approximately $15 \mathrm{mls}$ but a $4 \times 2 \mathrm{~cm}$ mass was palpable at the lower pole of the left testis. Laboratory investigations revealed: serum testosterone 37.1nmol/l (NV:10.0-38.0 nmol/l), LH<0.3U/L $(\mathrm{NV}: 3.0-12.0 \mathrm{U} / \mathrm{L})$, and FSH $<0.1 \mathrm{IU} / \mathrm{L}$ (NV:3.0-11.0 U/L). Serum b-HCG, aFP, LDH, oestradiol and inhibin levels were within the normal range. A repeated semen analysis confirmed azoospermia. Testicular ultrasound demonstrated a well-defined hypoechoic mass, measuring $31 \times 23 \times 17 \mathrm{~mm}$ and containing several flecks of calcification, arising from the lower pole of the left testis. A left orchidectomy was performed. Macroscopical histopathological examination revealed a single firm dark brown nodule $2.8 \mathrm{~cm}$ in diameter arising from the lower pole of the testis. The tumor distended the capsule of the testis without extending through it. Microscopical examination was consistent with a Leydig cell tumor. Computerised tomography of the chest, abdomen and pelvis was normal. Six months later, laboratory investigations revealed a serum testosterone of $14.3 \mathrm{nmol} / \mathrm{l}$, an $\mathrm{LH}$ of $5.4 \mathrm{U} / \mathrm{L}$ and an FSH of $4.3 \mathrm{U} / \mathrm{L}$, respectively. A repeated semen analysis was normal: volume $1.8 \mathrm{ml}(2-10 \mathrm{ml})$, count $124 \times 10^{6}(20$ $\left.350 \times 10^{6}\right)$, motility $80 \%(>60 \%)$, abnormal forms $<15 \%(<15 \%)$. Three months later his wife was pregnant. In summary, our patient presented with azoospermia, secondary to a Leydig cell tumor, which was reversible after removal of the tumor.
\end{abstract}

Key words: testicular Leydig cell tumor, infertility

A 35-year old woman and her 29-year old husband were referred to our infertility clinic with an eighteen month history of primary infertility. The female part-

Address correspondence and requests for reprints to: Dr A Markou, Unit of Metabolic Medicine, $1^{\text {st }}$ floor, Mint Wing, St Mary's Hospital, London NW8 9ST, Tel: +44 207 8861254 /1253, Fax: +44 207 8866037, e-mail: amarkouuk@yahoo.co.uk

Received 23-07-02, Revised 10-08-02, Accepted 02-09-02 ner had a regular 4/28day menstrual cycle. Her past medical history included a termination of pregnancy at 6 weeks, with another partner, ten years previously. Neither sexually transmitted diseases nor a history of pelvic inflammatory disease were reported. She had never had a surgical operation. She was on no medical treatment and she did not report any drug intake. She was a non-smoker and she reported no alcohol intake. 
The male partner was generally fit and well. $\mathrm{He}$ did not report any sexual dysfunction and shaved on a daily basis. He had never fathered children in the past.

His past medical history included an episode of Guilain-Barre syndrome with full recovery. He never had a surgical operation of the genitalia. There was no history of sexually transmitted diseases nor of any drug use. He was on no medical treatment.

He was a non-smoker and his alcohol intake was 10 units per week. The couple was having sexual intercourse 2-3 times a week with neither dyspareunia nor post-coital bleeding reported.

Examination of the female partner was unremarkable. Examination of the male partner revealed normal secondary sexual characteristics. Both testicles were of normal consistency with a volume of approximately $15 \mathrm{ml}$. A $4 \times 2 \mathrm{~cm}$ mass was palpable at the lower pole of the left testis.

Initial investigations including cycle monitoring confirmed ovulation of the female partner. A semen analysis revealed azoospermia. Laboratory investigations of the male partner were as follows: serum testosterone $36.9 \mathrm{nmol} / \mathrm{l}(\mathrm{NV}: 10.0-38.0 \mathrm{nmol} / \mathrm{l}), \mathrm{LH}<0.3$ $\mathrm{U} / \mathrm{L}(\mathrm{NV}: 3.0-12.0 \mathrm{U} / \mathrm{L}), \mathrm{FSH}<0.1 \mathrm{U} / \mathrm{L}(\mathrm{NV}: 3.0-$ $11.0 \mathrm{U} / \mathrm{L})$.

The suspicion of a hormones ecreting tumor was raised and further investigations followed. A testicular ultrasound scan demonstrated a well-defined hypoechoic mass on the lower pole of the left testis. It measured $31 \times 23 \times 17 \mathrm{~mm}$ and contained several flecks of calcification. It extended beyond the tunica to involve the epididymis laterally. A large varicocele was present. Normal sized right testis and epididymis were noted. Repeated laboratory investigations revealed: serum testosterone $37.1 \mathrm{nmol} / \mathrm{l}, \mathrm{LH}<0.3 \mathrm{U} / \mathrm{L}, \mathrm{FSH}$ $<0.1 \mathrm{U} / \mathrm{L}, \mathrm{HCG}<2 \mathrm{U} / \mathrm{L}(<5 \mathrm{U} / \mathrm{L})$, AFP $1.9 \mathrm{KU} / \mathrm{L}$ (<6KU/L), LDH: normal, estradiol 160nmol/l $(<170$ $\mathrm{nmol} / \mathrm{l})$. A repeated semen analysis reconfirmed azoospermia.

The normal HCG and AFP levels made it unlikely that this was a testicular germ cell tumor, the most likely diagnosis being a testosterone-secreting gonadal stromal tumor. The treatment of choice was surgical removal of the tumor and the patient duly underwent left orchidectomy. Although rare, malignancy should be considered in these cases. Computed tomography of the chest, abdomen and pelvis showed no evidence of metastatic disease.

\section{MACROSCOPIC HISTOPATHOLOGY OF LEFT TESTIS}

Testis $5 \times 3 \times 2.5 \mathrm{~cm}$ and spermatic cord with its coverings weighted 52 grams in total. There was a firm palpable lesion towards one apex at the junction with the epididymis. On sectioning, approximately $50 \%$ of the testicular mass was replaced by a single firm dark brown nodule, $2.8 \mathrm{~cm}$ in diameter at one pole of the testis. The tumor appeared to be distending the capsule of the testis without extending through it. Although in the region of the epididymis, it did not extend into the epididymal tissue.

\section{MICROSCOPIC HISTOPATHOLOGY}

LEFT TESTIS: Testis with a tumor of predominantly sheets and cords composed of polygonal cells with eosinophilic cytoplasm is a focally fibrous stroma. There was marked lipofuskin deposition especially at the periphery. The mitotic count was $<1 / 10 \mathrm{hpf}$. No capsular or vascular invasion was seen. The macroscopically normal area showed hypospermatogenesis, spermatogenesis being present to at least the spermatic stage (Johnsen score $=7$ ), but this was very patchy. There was no ITGN (intratubular germ cell neoplasia). Testis, Leydig cell tumor, completely excised.

RIGHT TESTIS: Testis with some mild interstitial fibrosis but seminiferous tubules were present with spermatogenesis at least to spermatocytes but very patchy $($ Johnsen score $=5)$.

Four months after the unilateral orchidectomy, a repeated semen analysis was normal: volume: $1.8 \mathrm{ml}$ (2-10ml), ph: 8.0 (7.9-8.1), viscosity: normal, motility: $80 \%$ (>60\%), sperm count: $124 \times 10 \cdot 6 / \mathrm{ml}(20-359 \times 10 \cdot 6 /$ $\mathrm{ml})$, abnormal forms: $<15 \%(<15 \%)$.

Laboratory investigations revealed: serum testosterone $14.3 \mathrm{nmol} / \mathrm{l}, \mathrm{LH}$ 5.4U/L, FSH 4.3U/L. Three months later his wife was pregnant.

\section{DISCUSSION}

Leydig cell tumors, although the most common of the gonadal-stromal neoplasms, are generally rare. 
They constitute $1-3 \%$ of all testicular tumors. They are most commonly unilateral, 3 to $9 \%$ have been estimated to be bilateral ${ }^{15}$. Only 1 of 40 patients in a series reported by Kim et al in 1985 had a metachronous bilateral tumor.

These tumors can develop in both children and adults. In children they develop most frequently between the ages of 4 and 10 years and account for $10 \%$ of cases of precocious puberty. In adults they develop most frequently between the ages of 30 and 60 years. Men usually present with either an asymptomatic mass or with endocrine abnormalities such as gynaecomastia $(20-40 \%)$ or loss of libido. Azoospermia is not usually reported as a symptom of this tumor. Four more cases have been reported in the literature describing azoospermia as the presenting symptom ${ }^{3,17,18}$. Leydig cell tumors can be non hormone-secreting or associated with autonomous secretion of steroid hormones.

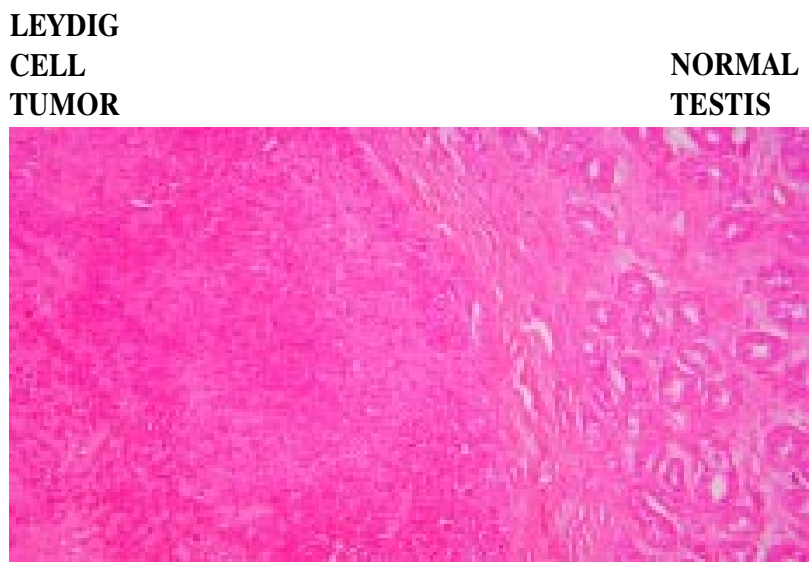

Figure 1. Histology of the leydig cell tumor and the normal testis.

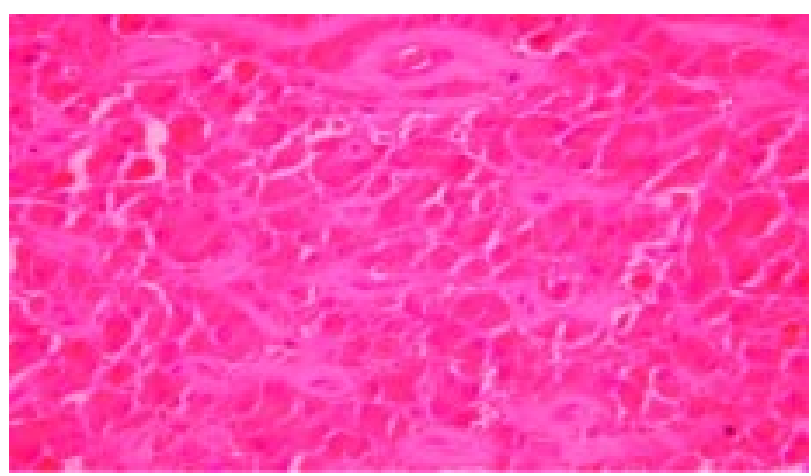

Figure 2. High power view to show leydig cell tumor with eosinophilic cytoplasm \& regular nuclei.
The most commonly produced are testosterone and estrogen. Concentrations of other androgens, including dehydroepiandrosterone, androstenedione, 17hydroxyprogesterone, are usually normal. The serum gonadotropin levels are usually low. This case involved a testosterone-secreting tumor. The mechanism of azoospermia is likely to be autonomous production of testosterone by the abnormal left testis leading to suppression of gonadotrophins and impaired spermatogenesis in both the uninvaded normal tissue of the left testis and the otherwise normal right testis, as described by the low Johnsen score levels. This is supported by the fact that tumor removal resulted in complete normalization of spermatogenesis. Also, a study evaluating the effect of testicular tumors on spermatogenesis showed that in non-hormone- secreting benign Leydig cell tumors, spermatogenesis was relatively uniform and complete in both near and far areas to the tumor of the ipsilateral testis ${ }^{14}$. In contrast, malignant testicular tumors (either germ cell or non germ cell) demonstrated markedly impaired spermatogenesis throughout the testis, being particularly impaired in areas adjacent to the tumor ${ }^{14,16}$. These results suggested that impairment of spermatogenesis may be mediated by humoral or local factors either secreted by the tumors or elicited in response to malignancy. Although cryptorchidism is considered to be a risk factor for developing germ cell tumors, there have been reported cases of Leydig cell tumors with a history of cryptorchidism ${ }^{3,11}$. Klinefelter syndrome has also been described ${ }^{12}$, as well as familial occurrence ${ }^{13}$.

Leydig cell tumors are mostly benign but $10 \%$ of them have the potential of metastasizing. The commonest metastatic sites are regional lymph nodes, lung, liver and bones. The metastatic varieties occur exclusively in adults ${ }^{4}$ and are more common in older patients with an average age of more than 60 years ${ }^{2}$. A $20 \%$ occurrence of the metastatic disease at the time of diagnosis and a $40 \%$ metastatic involvement within 2 years ${ }^{5}$ have been reported. Unfortunately, when making a diagnosis, there are no prognostic factors that could predict the malignant character of these tumors. The size and mitotic activity of the original tumor appear to be the best predictors of outcome ${ }^{6-8}$. The clinical manifestations of hormone production, as factors of prognostic value, rarely occur in the metastatic processes ${ }^{9,10}$. In our case, the age of the patient, the size of the tumor, the low mitotic activity and the absence of capsular or vascular invasion and 
metastases are in favor of a benign course. Nevertheless, regular follow-up is recommended.

Inguinal orchidectomy should be performed in every patient in order to remove the primary tumor and to establish the diagnosis. Some support the prophylactic retro-peritoneal lymph node dissection even in patients with clinical stage I tumors (tumor confined to the testis $)^{4,5}$. Radiotherapy and chemotherapy have proved to be ineffective. Surgical treatment seems to be the only way of effectively curing these testicular tumors because of the lack of systemic therapeutic alternatives.

This case reinforces the importance of clinical examination and use of imaging investigations in the evaluation of the infertile male.

\section{CONCLUSION}

This is an unusual case of azoospermic male infertility due to the presence of a benign, testosteronesecreting, Sertoli-Leydig cell tumor of the testis. Removal of the tumor resulted in restoration of the normal pituitary-gonadal axis, resumption of spermatogenesis and fertility.

\section{REFERENCES}

1. Zarilli S, Lombardi G, Paesano L, di Somma C, Colao A, Mirone V, de Rosa M, 2000 Hormonal and seminal evaluation of Leydig cell tumor patients before and after orchidectomy. Andrologia 32: 147-154.

2. Rich MA, Keating MA, 2000 Leydig cell tumors and tumors associated with congenital adrenal hyperplasia. Pediatric Urology Oncology 27: 519-527.

3. Fallick ML, Lin WW, Lipshultz LI, 1999 Leydig cell tumors presenting as azoospermia. The Journal of Urology 161: 1571-1572.

4. Farkas LM, Szekely JG, Pusztai C, Baki M, 2000 High Frequency of Metastatic Leydig Cell Testicular Tumors. Oncology 59: 118-121.

5. Bertram KA, Bratloff B, Hodges GF, Davidson M, 1991
Treatment of malignant Leydig cell tumor. Cancer 68: 2324-2329.

6. Coakley FV, Hricak H, Presti JC, 1998 Imaging and management of atypical testicular masses. Urol Clin North Am 25: 375-382.

7. Cheville JC,1999 Classification and pathology of testicular germ cell and cord-stromal tumors. Urol Clin North Am 26: 595-609.

8. Middendorff R, Davidoff MS, Mayer B, Holstein AF, 1995 Neuroendocrine characteristics of human Leydig cell tumors. Andrologia 27: 351-355.

9. Shapiro CM, A Sankovitch A, Yoon WJ,1988 Malignant feminizing Leydig cell tumor. J Surg Oncol 27: 73-75.

10. Unluer E, Ozcan D, Altin S, 1990 Malignat Leydig cell tumor of the testis: Acase report and review of the literature. Int Urol Nephrol 22: 455-460.

11. Kirsh AJ, Bastian W, Cohen HL, Glassberg KI, 1993 Precocious puberty in a child with unilateral Leydig cell tumor of the testis following orchidopexy. J Urol 150: 14831485.

12. Kim I, Young RH, Scully RE, 1985 Leydig cell tumor of the testis: a clinicopathological analysis of 40 cases and review of the literature. Am J Surg Pathol 9: 177-192.

13. Bokemeyer C, Kuczyk M, Schoffsky P, Schmoll HJ, 1993 Familial occurrence of Leydig cell tumors: a report of a case in a father and his adult son. J Urol 150: 1509-1510.

14. Ho GT, Gardner H, Mostofi K, de Wolf WC, Loughlin KR, Morgentaler A,1994 The effect of testicular nongerm cell tumors on local spermatogenesis. Fertility \& Sterility 62: 162-166.

15. Mostofi FK, Price EB 1973 Tumors of the male genital system. Atlas of Tumor Pathology. Armed Forces Institute of Pathology: Washington, DC; 8: pp, 86-99.

16. Ho GT, Gardner H, de Wolf WC, Loughlin KR, 1992 A Morgentaler Influence of testicular carcinoma on ipsilateral spermatogenesis. J Urol 148: 821-5.

17. Mostafid H, Nawrocki J, Fletcher MS, Vaughan NJ, Melcher DH, 1998 Leydig cell tumor of the testis: a rare cause of male infertility. Br J Urol 81: 651.

18. Kodoh N, Koh E, Nakamura M, Namiki M, Kiyohara H, Okiyama A, Sonoda T, 1991 Bilateral Leydig cell tumors and male infertility: case report. Urol Int 46: 104-6.

19. Sciarra A, Casale P, di Nicola S, di Chiro C, di Silverio F, 1998 Hormonal profile of patients with Leydig cell tumors: a urologic cause of gynaecomastia. Minerva Urol Nefrol 50: 241-6. 